\title{
Analisis Korelasi Kanonik pada Kualitas Air Sungai Ciliwung ${ }^{\star}$
}

\author{
Nadya Amelia Dewi Suryana ${ }^{1}$, Itasia Dina Sulvianti ${ }^{2 \ddagger}$, Muhammad \\ Nur Aidi ${ }^{3}$ \\ ${ }^{123}$ Department of Statistics, IPB University, Indonesia \\ ‡corresponding author: itasiasu@apps.ipb.ac.id
}

Copyright @ 2021 Nadya Amelia Dewi Suryana, Itasia Dina Sulvianti, and Muhammad Nur Aidi. This is an open-access article distributed under the Creative Commons Attribution License, which permits unrestricted use, distribution, and reproduction in any medium, provided the original work is properly cited.

\begin{abstract}
Water is an important factor in fulfilling the needs of living things, therefore the water that is used must be free from bacterias and do not contain any toxic substances. The most common water source comes from the river. Ciliwung River as one of the main rivers used for drinking, household needs, industrial needs, and transportation must have good water quality. Therefore, the Ciliwung River water quality needed to be known. The water quality is measured based on the parameters such as the physical water quality and the chemical water quality. The measurement of those parameters are classified to be complicated as it measured by laboratorium research, so that the identification of the chemical water quality parameter could be done through the physical water quality that is easier and simpler to be measured. This study aims to determine the variable of the physical water parameters that can be used to identify the chemical water quality parameters, so that the water quality of the Ciliwung River can be known in a simpler way. Statistical method that can be used to see the relationship between the two variable groups is the canonical correlation analysis. Canonical correlation analysis is a method in multiple variable analysis used to investigate the relationship of two groups of variables using the linear combination principle of the two variables. Based on the results of the canonical correlation analysis, it can be concluded that there is a relationship between the physical quality of water and the chemical quality of water. The correlation exists between the variables of physical quality of water, which are the water temperature and the content of suspended substances in water, with the variables of chemical quality of water, namely groups of metals (manganese levels in water and iron content in water) and groups of acid (the level of deep phosphate in water, the level of sulfate in water, the level of nitrite in water, and the level of nitrate in water). The relationship between the physical quality of water is positive between the temperature of water and the chemical quality of water whereas negative between the levels of suspended substances in water and the chemical quality of water.
\end{abstract}

Keywords: canonical correlation, ciliwung. water quality.

\section{Pendahuluan}

* Received: Feb 2019; Reviewed: May 2021; Published: May 2021 


\subsection{Latar Belakang}

Air merupakan faktor penting dalam pemenuhan kebutuhan bagi mahluk hidup, diantaranya sebagai air minum, keperluan industri, keperluan pertanian, maupun keperluan rumah tangga. Air juga memiliki peran penting dalam proses pencernaan, proses metabolisme, proses pengangkutan zat-zat makanan dalam tubuh, mengatur keseimbangan suhu tubuh, dan menjaga tubuh dari kekeringan sehingga air yang digunakan harus bebas dari kuman penyakit dan tidak mengandung bahan beracun. Berdasarkan Keputusan Menteri Kesehatan Republik Indonesia Nomor 1405/MENKES/SK/XI/2002 tentang Persyaratan Kesehatan Lingkungan Kerja Perkantoran dan Industri, pengertian air bersih yaitu air yang dipergunakan untuk keperluan sehari-hari dan kualitasnya memenuhi persyaratan kesehatan air bersih sesuai dengan peraturan perundang-undangan yang berlaku dan dapat diminum apabila dimasak.

Menurut Djarismawati (1991) sumber air yang paling banyak digunakan adalah air sungai, namun dengan meningkatnya kepadatan jumlah penduduk dan pembangunan di masyarakat mengakibatkan tingkat pencemaran air sungai ikut meningkat sehingga banyak aliran air sungai yang tercemar dan tidak lagi layak dikonsumsi untuk berbagai kebutuhan. Salah satu sungai yang memiliki peranan penting bagi pemenuhan kebutuhan masyarakat Indonesia adalah Sungai Ciliwung.

Sungai Ciliwung sebagai salah satu sungai yang berfungsi sebagai sumber mata air yang digunakan untuk keperluan air minum, sumber air untuk kebutuhan rumah tangga, keperluan industri, dan transportasi harus memiliki kualitas air yang layak untuk digunakan, sehingga kualitas air yang digunakan penting untuk diketahui. Kualitas air tersebut dapat diketahui dari parameter kualitas fisik air dan kualitas kimia air. Pengukuran kedua kualitas air tersebut tergolong rumit khususnya kualitas kimia air yang pengukurannya harus dilakukan di laboratorium, sehingga diharapkan kualitas fisik air dapat digunakan sebagai peubah untuk menentukan kualitas air melalui hubungan antara kualitas fisik air dan kualitas kimia air.

Kualitas air dapat diidentifikasi melalui parameter kualitas fisik air yaitu dengan mengetahui hubungan antara parameter kualitas fisik air dengan parameter kualitas kimia air. Metode yang digunakan untuk mengetahui hubungan antara dua parameter kualitas air tersebut adalah analisis korelasi kanonik, yaitu metode dalam analisis peubah ganda yang digunakan untuk menyelidiki hubungan antara dua gugus peubah menggunakan prinsip kombinasi linear dari peubah-peubah pada kedua gugus peubah tersebut sedemikian sehingga korelasi di antara kedua gugus peubah tersebut menjadi maksimum.

\subsection{Tujuan Penelitian}

Tujuan dari penelitian ini adalah menentukan peubah parameter kualitas fisik air yang dapat digunakan untuk mengidentifikasi parameter kualitas kimia air sehingga kualitas air Sungai Ciliwung dapat diketahui dengan cara yang lebih sederhana.

\section{Tinjauan Pustaka}

\subsection{Parameter Kualitas Kimia Air}

Air bersih yang baik adalah air yang tidak tercemar secara berlebihan oleh zat-zat kimia yang berbahaya bagi kesehatan. Kandungan zat kimia dalam air bersih yang digunakan sehari-hari hendaknya tidak melebihi kadar maksimum yang diperbolehkan seperti tercantum dalam Peraturan Menteri Kesehatan RI nomor 
416/MENKES/PER/IX/1990. Peubah-peubah parameter kualitas kimia air sebanyak dua puluh empat ditampilkan pada Tabel 1. Penggunaan air yang mengandung bahan kimia beracun dan zat-zat kimia yang melebihi kadar maksimum yang diperbolehkan dapat berakibat buruk bagi kesehatan manusia.

Tabel 1: Peubah parameter kualitas kimia air

\begin{tabular}{lll}
\hline No & $\begin{array}{l}\text { Peubah parameter kualitas } \\
\text { kimia air }\end{array}$ & $\begin{array}{l}\text { No } \\
\text { Peubah parameter kualitas } \\
\text { kimia air }\end{array}$ \\
\hline 1 & Kadaramoniakbebas $\left(\mathrm{NH}_{3}-\mathrm{N}\right)$ & 13 Kadar nitrit $\left(\mathrm{NO}_{2}-\mathrm{N}\right)$ \\
2 & Kadar besi (Fe) & 14 Kadar oksigen terlarut \\
3 & Kadar detergen (MBAS) & 15 Kadar pH \\
4 & Kadar fenol & 16 Kadar seng $(\mathrm{Zn})$ \\
5 & Kadar fosfat total $\left(\mathrm{PO}_{4}\right)$ & 17 Kadar sulfat $\left(\mathrm{SO}_{4}\right)$ \\
6 & Kadar cadmium $(\mathrm{Cd})$ & 18 Kadar tembaga $(\mathrm{Cu})$ \\
7 & Kadar BOD & 19 Kadar timbal $(\mathrm{Pb})$ \\
8 & Kadar COD & 20 Kadar air raksa $(\mathrm{Hg})$ \\
9 & Kadar kromium $\mathrm{VI}(\mathrm{Cr})$ & 21 Kadar arsen $(\mathrm{As})$ \\
10 & Kadar mangan $(\mathrm{Mn})$ & 22 Kadar sianida $(\mathrm{CN})$ \\
11 & Kadar minyak-lemak & 23 Kadar klorin bebas $\left(\mathrm{Cl}_{2}\right)$ \\
12 & Kadar nitrat $\left(\mathrm{NO}_{3}-\mathrm{N}\right)$ & 24 Kadar sulfida $\left(\mathrm{H}_{2} \mathrm{~S}\right)$ \\
\hline & &
\end{tabular}

\subsection{Parameter Kualitas Kimia Air}

Peraturan Menteri Kesehatan RI nomor 416/MENKES/PER/IX/1990, menyatakan bahwa air yang layak dikonsumsi dan digunakan dalam kehidupan sehari-hari adalah air yang mempunyai kualitas yang baik sebagai sumber air minum maupun air baku (air bersih), antara lain harus memenuhi persyaratan secara fisik, tidak berbau, tidak berasa, tidak keruh, serta tidak berwarna. Peubah-peubah parameter kualitas fisik air sebanyak empat peubah disajikan pada Tabel 2.

\begin{tabular}{cl} 
Tabel 2: & Peubah parameter kualitas fisik air \\
\hline No & Peubah kualitas fisik air \\
\hline 1 & Kandungan DHL \\
2 & Temperatur air \\
3 & Kadar zat terlarut (TDS) \\
4 & Kadar zat tersuspensi (TSS) \\
\hline
\end{tabular}

\subsection{Kualitas Air Bersih}

Sebagai organisasi kesehatan internasional, World Health Organization (WHO) mengeluarkan peraturan tentang syarat-syarat kualitas air bersih yang diukur dengan parameter kualitas fisik air, parameter kualitas kimia air, dan parameter kualitas biologi air. Peraturan yang ditetapkan oleh WHO tersebut digunakan sebagai pedoman bagi negara anggota. Namun demikian masing-masing negara anggota, dapat pula menetapkan syarat-syarat kualitas air sesuai dengan kondisi negara tersebut.

Berdasarkan Keputusan Menteri Kesehatan Republik Indonesia Nomor 1405/MENKES/SK/XI/2002 tentang Persyaratan Kesehatan Lingkungan Kerja Perkantoran dan Industri, air bersih adalah air yang dipergunakan untuk keperluan 
sehari-hari dan kualitasnya memenuhi persyaratan kesehatan air bersih sesuai dengan peraturan perundang-undangan yang berlaku dan dapat diminum apabila dimasak.

Demikian pula halnya dengan air yang digunakan sebagai kebutuhan air bersih sehari-hari, sebaiknya air tersebut tidak berwarna, tidak berasa, tidak berbau, jernih, dan mempunyai suhu yang sesuai dengan standar yang ditetapkan. Jika salah satu dari syarat tersebut tidak terpenuhi maka besar kemungkinan air itu tidak sehat karena mengandung beberapa zat kimia, mineral, ataupun zat organik/biologis yang dapat mengubah warna, rasa, bau, dan kejernihan air. Pengukuran kedua kualitas air tersebut tergolong rumit khususnya kualitas kimia air yang pengukurannya harus dilakukan di laboratorium, sehingga dilakukan identifikasi parameter kualitas kimia air melalui parameter kualitas fisik air yang pengukurannya lebih mudah dan lebih sederhana untuk dilakukan.

\subsection{Penggerombolan Tidak Berhierarki}

Analisis gerombol merupakan teknik peubah ganda yang bertujuan untuk mengelompokkan objek-objek dengan tingkat kemiripan karakteristik tinggi ke dalam satu gerombol, sedangkan karakteristik antar objek pada suatu gerombol dengan gerombol lain memiliki tingkat kemiripan rendah. Metode penggerombolan tidak berhierarkhi digunakan untuk menggerombolkan pengamatan yang kemiripan sifat dan banyaknya gerombol yang diinginkan telah diketahui. Dalam bentuk yang paling sederhana, algoritma dalam penentuan suatu objek ke dalam gerombol tertentu berdasarkan rataan terdekat terdiri dari tiga tahap:

1. Membagi objek-objek yang diteliti ke dalam $\mathrm{k}$ gerombol awal.

2. Memindahkan tiap objek ke suatu gerombol berdasarkan rataan terdekat dan ke gerombol lain dengan jarak terjauh. Jarak ditentukan dengan menggunakan jarak Euclidean.

dengan :

$$
d(i, j)=\left[\sum_{i=1}^{p}\left(\bar{X}_{i}-\bar{X}_{j}\right)^{2}\right]^{\frac{1}{2}}
$$

$d(i, j)=$ jarak antara gerombol $i$ ke gerombol $j$

$\bar{X}_{i}=$ nilai tengah pada gerombol ke $i$

$\bar{X}_{j}=$ nilai tengah pada gerombol ke $j$

$p$ = banyaknya peubah yang diamati

3. Mengulangi langkah 2 sampai tidak ada lagi pemindahan objek antar gerombol hingga jarak antar gerombol besar dan dalam gerombol kecil (Matjik AA 2011).

\subsection{Analisis Korelasi Kanonik}

Analisis korelasi kanonik merupakan salah satu metode dalam analisis peubah ganda yang digunakan untuk mengidentifikasi dan mengkuantifikasi hubungan antara kelompok peubah $\mathbf{Y}\left(y_{1}, y_{2}, y_{q}\right)$ dengan dengan kelompok peubah $\mathbf{X}$ $\left(x_{1}, x_{2}, x_{p}\right)$ menggunakan prinsip kombinasi linier dari setiap kelompok peubah sedemikian sehingga korelasi di antara kedua kelompok peubah tersebut menjadi maksimum (Matjik AA 2011).

Misal dibuat hubungan antara kelompok peubah $y_{1}, y_{2}, y_{q}$ yang dinotasikan dengan vektor peubah acak $\mathbf{Y}$, dengan kelompok peubah $x_{1}, x_{2}, x_{p}$ yang dinotasikan 
dengan vektor peubah acak $\mathbf{X}$, dengan $q p$ (RA Johnsen 2007).

memiliki vektor rataan

$$
Z=\left[\begin{array}{c}
X \\
\cdots \\
Y
\end{array}\right]=\left[\begin{array}{c}
X_{1} \\
X_{2} \\
\vdots \\
X_{p} \\
\cdots \\
Y_{1} \\
Y_{2} \\
\vdots \\
Y_{p}
\end{array}\right]
$$

dan matriks ragam peragam

$$
\underline{\mu}=\mathrm{E} Z=\left[\begin{array}{c}
\mathrm{E}(X) \\
\cdots \\
\mathrm{E}(Y)
\end{array}\right]=\left[\begin{array}{c}
\underline{\mu}_{x} \\
\cdots \\
\underline{\mu}_{y}
\end{array}\right]
$$

$$
\begin{aligned}
\Sigma= & \mathrm{E}(Z-\underline{\mu})(Z-\underline{\mu})^{\prime} \\
& =\left[\begin{array}{ccc}
\Sigma_{\mathrm{XX}} & \vdots & \Sigma_{\mathrm{YX}} \\
\cdots & \vdots & \cdots \\
\Sigma_{\mathrm{XY}} & \vdots & \Sigma_{\mathrm{YY}}
\end{array}\right]
\end{aligned}
$$

Misalkan karakteristik dari vektor peubah acak $\mathbf{X}$ dan $\mathbf{Y}$ adalah sebagai berikut (Matjik AA 2011):

$$
\begin{array}{lll}
E(X)=\mu_{x} & & \operatorname{Var}(X)=\Sigma_{\mathrm{XX}} \\
E(X)=\mu_{y} & \operatorname{Var}(Y)=\Sigma_{\mathrm{YY}} \\
& \operatorname{Cov}(X Y)=\Sigma_{\mathrm{XY}}=\Sigma_{\mathrm{YX}} &
\end{array}
$$

Vektor $Y$ ditransformasi ke $W_{k}$, dengan $W_{k}$ tegak lurus $W_{i}$ dan $l \neq k$ melalui proses komponen utama. Vektor $X$ ditransformasi ke $V_{k}$, dengan $V_{k}$ tegak lurus $V_{l}$ dan $l \neq k$ juga diperoleh melalui proses komponen utama sehingga diperoleh fungsi kanonik pertama (RA Johnsen 2007)

$$
V_{l}=e_{l}{ }^{\prime} \sum_{x x}^{-\frac{1}{2}} X \quad W_{l}=f_{l}{ }^{\prime} \sum_{y y}^{-\frac{1}{2}} Y
$$

hingga fungsi kanonik ke-k, dengan $k=2,3, \ldots, p$

$$
V_{k}=e_{k}{ }^{\prime} \sum_{x x}^{-\frac{1}{2}} X \quad W_{k}=f_{k}{ }^{\prime} \sum_{y y}^{-\frac{1}{2}} Y
$$

dengan memaksimumkan

$$
\max (a, b) \operatorname{Cor}\left(V_{k} W_{k}\right)=\rho_{k}^{2}
$$

sehingga diperoleh $\rho_{1}^{2} \geq \rho_{2}^{2} \geq \cdots \geq \rho_{k}^{2}$ yang merupakan akar ciri dari matriks $\Sigma_{\mathrm{XX}}{ }^{-\frac{1}{2}} \Sigma_{\mathrm{XY}} \Sigma_{\mathrm{YY}}{ }^{-\frac{1}{2}} \Sigma_{\mathrm{YX}} \Sigma_{\mathrm{XX}}{ }^{-\frac{1}{2}}$ yang berpadanan dengan vektor ciri $e_{1}, e_{2}, \ldots, e_{p}$. Akar ciri tersebut juga merupakan akar ciri dari matriks $\Sigma_{\mathrm{YY}}{ }^{-\frac{1}{2}} \Sigma_{\mathrm{YX}} \Sigma_{\mathrm{XI}}-\frac{1}{2} \Sigma_{\mathrm{XY}} \Sigma_{\mathrm{XX}}{ }^{-\frac{1}{2}}$ yang berpadanan dengan vektor ciri $f_{1}, f_{2}, \ldots, f_{p}$. Fungsi kanonik yang diperoleh memiliki sifat:

dengan $k, l=1,2, \ldots, p$.

$$
\begin{aligned}
\operatorname{Var}\left(V_{k}\right) & =\operatorname{Var}\left(W_{k}\right)=1 \\
\operatorname{Cov}\left(V_{k}, V_{l}\right) & =\operatorname{Corr}\left(V_{k}, V_{l}\right)=0 \\
\operatorname{Cov}\left(W_{k}, W_{l}\right) & =\operatorname{Corr}\left(W_{k}, W_{l}\right)=0 \\
\operatorname{Cov}\left(V_{k}, W_{l}\right) & =\operatorname{Corr}\left(W_{k}, V_{l}\right)=0
\end{aligned}
$$


Kombinasi linear dari kedua kelompok peubah tersebut dapat dituliskan sebagai berikut:

Sehingga

$$
\begin{aligned}
& V=\underline{a}^{\prime} X=a_{1} X_{1}+a_{2} X_{2}+\cdots+a_{p} X_{p} \\
& W=\underline{b}^{\prime} Y=b_{1} Y_{1}+b_{2} Y_{2}+\cdots+b_{q} Y_{q}
\end{aligned}
$$

$$
\begin{gathered}
\operatorname{Var}(V)=\underline{a}^{\prime} \operatorname{Cov}(X) \underline{a}=\underline{a}^{\prime} \Sigma_{\mathrm{xx}} \underline{a} \\
\operatorname{Var}(W)=\underline{b}^{\prime} \operatorname{Cov}(X) \underline{b}=\underline{b}^{\prime} \Sigma_{\mathrm{yy}} \underline{b} \\
\operatorname{Cov}(V, W)=\underline{a}^{\prime} \operatorname{Cov}(X, Y) \underline{b}=\underline{a}^{\prime} \Sigma_{\mathrm{xy}} \underline{b}
\end{gathered}
$$

Korelasi kanonik diperoleh dengan memaksimumkan nilai :

dengan $i=1,2, \ldots, k$.

$$
\operatorname{Corr}\left(V_{i}, W_{i}\right)=\rho_{i}=\frac{\underline{a}_{i}^{\prime} \Sigma_{\mathrm{xy}} \underline{b}_{i}}{\sqrt{\left(\underline{a}_{i}{ }^{\prime} \Sigma_{\mathrm{xx}} \underline{a}_{i}\right)\left(\underline{b}_{i}{ }^{\prime} \Sigma_{\mathrm{yy}} \underline{b}_{i}\right)}}
$$

Didefinisikan pasangan pertama dari peubah kanonik adalah kombinasi linear $\left(V_{1}, W_{1}\right)$ yang memiliki ragam satu dan korelasinya terbesar; pasangan kedua dari peubah kanonik adalah kombinasi linear $\left(V_{2}, W_{2}\right)$ yang memiliki ragam satu dan korelasi terbesar kedua serta tidak berkorelasi dengan peubah kanonik yang pertama, dan pasangan ke-k dari peubah kanonik adalah kombinasi linear $\left(V_{k}, W_{k}\right)$ yang memiliki ragam satu dan korelasinya terbesar ke-k serta tidak berkorelasi dengan peubah kanonik $1,2, \ldots, k-1$, sehingga dapat dituliskan sebagai berikut:

Fungsi kanonik pertama

$$
\begin{aligned}
& V_{1}=\underline{a}_{1}{ }^{\prime} X \\
& W_{1}=\underline{b}_{1}{ }^{\prime} Y
\end{aligned}
$$

$$
\begin{gathered}
\operatorname{Var}\left(V_{1}\right)=1 \\
\operatorname{Var}\left(W_{1}\right)=1
\end{gathered}
$$

Fungsi kanonik ke-2

$$
\begin{aligned}
& V_{2}=\underline{a}_{2}{ }^{\prime} X \\
& W_{2}=\underline{b}_{2}{ }^{\prime} Y
\end{aligned}
$$

$\operatorname{Maksimum} \operatorname{Corr}\left(V_{1}, W_{1}\right)=\rho_{1}$ 
1. Weight kanonik merupakan besarnya kontribusi peubah asal terhadap peubah kanonik. Semakin besar nilai koefisien ini maka semakin besar kontribusi peubah yang bersangkutan terhadap peubah kanonik.

2. Loadings kanonik dapat dihitung dari korelasi antara peubah asal dengan masing-masing peubah kanoniknya. Semakin besar nilai loading mencerminkan semakin dekat hubungan fungsi kanonik yang bersangkutan dengan peubah asal. Loadings kanonik dibedakan menjadi:

dengan:

$$
\begin{aligned}
R_{x v} & =R_{x x} \underline{a} \\
R_{y w} & =R_{y y} \underline{b}
\end{aligned}
$$

$R_{x v} \quad$ : Muatan kanonik peubah $\mathrm{X}$

$R_{y w} \quad:$ Muatan kanonik peubah $\mathrm{Y}$

$R_{x x} \quad$ : Korelasi antar peubah $\mathrm{X}$

$R_{y y} \quad$ : Korelasi antar peubah $\mathrm{Y}$

$\underline{a} \quad$ : Vektor koefisien kanonik peubah $\mathrm{V}$

$\underline{b} \quad$ : Vektor koefisien kanonik peubah $\mathrm{W}$

3. Cross loadings kanonik dapat dihitung dari korelasi antara peubah asal dengan bukan peubah kanoniknya. Semakin besar nilai loading mencerminkan semakin dekat hubungan fungsi kanonik yang bersangkutan dengan peubah asal. Cross loading kanonik terdiri dari:

dengan:

$$
\begin{aligned}
& R_{x w}=R_{x v} \underline{a} \\
& R_{y v}=R_{y w} \underline{b}
\end{aligned}
$$

$R_{x w} \quad$ : Muatan silang kanonik peubah $\mathrm{X}$

$R_{y v} \quad$ : Muatan silang kanonik peubah $\mathrm{Y}$

$R_{x v} \quad$ : Muatan kanonik peubah $\mathrm{X}$

$R_{y w}:$ Muatan kanonik peubah $\mathrm{Y}$

$\rho_{i} \quad$ : Korelasi kanonik ke-i, $i=1,2, \ldots, k$

\section{Metodologi}

\subsection{Sumber Data}

Data yang digunakan merupakan data sekunder hasil pengukuran mingguan kualitas fisik dan kualitas kimia air Sungai Ciliwung terhitung bulan Januari 2012 hingga November 2016 sebanyak 256 amatan yang diperoleh dari Badan Pengelolaan

Lingkungan Hidup Daerah (BPLHD) Provinsi Jawa Barat. Peubah yang digunakan pada penelitian ini terbagi menjadi dua kelompok parameter kualitas air, yaitu parameter kualitas fisik air dan parameter kualitas kimia air (Tabel 3).

\subsection{Prosedur Analisis Data}

Metode yang digunakan pada penelitian ini adalah analisis korelasi kanonik dengan langkahlangkah sebagai berikut:

1. Melakukan pendeteksian missing value pada peubah-peubah parameter kualitas air.

2. Menghitung matriks korelasi antara peubahpeubah parameter kualitas fisik air dan peubahpeubah parameter kualitas kimia air. 
3. Mencari pengelompokan peubah-peubah parameter kualitas fisik air dan peubah-peubah parameter kualitas kimia air yang baru.

4. Mencari fungsi kanonik dan korelasi kanonikserta menghitung nilai koefisien determinasi dari kedua peubah-peubah parameter kualitas air yang sudah dikelompokkan.

5. Menentukan fungsi kanonik yang akan diinterpretasi.

6. Melakukan interpretasi fungsi kanonik.

Tabel 3: Nilai yang dihasilkan ditampilkan pada tabel.

\begin{tabular}{|c|c|c|}
\hline Peubah & Keterangan & Satuan \\
\hline$Y_{1}$ & Kandungan DHL dalam air & umhos/cm \\
\hline$Y_{2}$ & Temperatur air & ${ }^{0} \mathrm{C}$ \\
\hline$Y_{3}$ & Kadar zat terlarut (TDS) dalam air & $\mathrm{mg} / \mathrm{L}$ \\
\hline$Y_{3}$ & Kadar zat tersuspensi (TSS) dalam air & $\mathrm{mg} / \mathrm{L}$ \\
\hline$X_{1}$ & Kadar amoniak bebas $\left(\mathrm{NH}_{3}-\mathrm{N}\right)$ dalam air & $\mathrm{mg} / \mathrm{L}$ \\
\hline$x_{2}$ & Kadar besi (Fe) dalam air & $\mathrm{mg} / \mathrm{L}$ \\
\hline$x_{3}$ & Kadar detergen (MBAS) dalam air & $\mu \mathrm{g} / \mathrm{L}$ \\
\hline$X_{4}$ & Kadar fenol dalam air & $\mu \mathrm{g} / \mathrm{L}$ \\
\hline$X_{5}$ & Kadar fosfat total $\left(\mathrm{PO}_{4}\right)$ dalam air & $\mathrm{mg} / \mathrm{L}$ \\
\hline$X_{6}$ & Kadar cadmium (Cd) dalam air & $\mathrm{mg} / \mathrm{L}$ \\
\hline$X_{7}$ & Kadar BOD dalam air & $\mathrm{mg} / \mathrm{L}$ \\
\hline$X_{8}$ & Kadar COD dalam air & $\mathrm{mg} / \mathrm{L}$ \\
\hline$X_{9}$ & Kadar kromium VI (Cr) dalam air & $\mathrm{mg} / \mathrm{L}$ \\
\hline$x_{10}$ & Kadar mangan (Mn) dalam air & $\mathrm{mg} / \mathrm{L}$ \\
\hline$X_{11}$ & Kadar minyak-lemak dalam air & $\mathrm{mg} / \mathrm{L}$ \\
\hline$X_{12}$ & Kadar nitrat $\left(\mathrm{NO}_{3}-\mathrm{N}\right)$ dalam air & $\mu \mathrm{g} / \mathrm{L}$ \\
\hline$X_{13}$ & Kadar nitrit $\left(\mathrm{NO}_{2}-\mathrm{N}\right)$ dalam air & $\mathrm{mg} / \mathrm{L}$ \\
\hline$X_{14}$ & Kadar oksigen terlarut dalam air & $\mathrm{mg} / \mathrm{L}$ \\
\hline$X_{15}$ & Kadar pH dalam air & $\mathrm{mg} / \mathrm{L}$ \\
\hline$x_{16}$ & Kadar seng (Zn) dalam air & - \\
\hline$X_{17}$ & Kadar sulfat $\left(\mathrm{SO}_{4}\right)$ dalam air & $\mathrm{mg} / \mathrm{L}$ \\
\hline$X_{18}$ & Kadar tembaga $(\mathrm{Cu})$ dalam air & $\mathrm{mg} / \mathrm{L}$ \\
\hline$X_{19}$ & Kadar timbal $(\mathrm{Pb})$ dalam air & $\mathrm{mg} / \mathrm{L}$ \\
\hline$x_{20}$ & Kadar air raksa $(\mathrm{Hg})$ dalam air & $\mathrm{mg} / \mathrm{L}$ \\
\hline$x_{21}$ & Kadar arsen (As) dalam air & $\mathrm{mg} / \mathrm{L}$ \\
\hline$x_{22}$ & Kadar sianida $(\mathrm{CN})$ dalam air & $\mathrm{mg} / \mathrm{L}$ \\
\hline$x_{23}$ & Kadar khlorin bebas $(\mathrm{Cl} / 2)$ dalam air & $\mathrm{mg} / \mathrm{L}$ \\
\hline$X_{24}$ & Kadar sulfide $\left(\mathrm{H}_{2} \mathrm{~S}\right)$ dalam air & $\mathrm{mg} / \mathrm{L}$ \\
\hline
\end{tabular}

\section{Hasil dan Pembahasan}

Pendeteksian missing value dilakukan secara manual pada data dengan mengecek kelengkapan pasangan data dari kedua kelompok peubah. 


\subsection{Analisis Korelasi Kanonik}

Sebelum dilakukan analisis korelasi kanonik, terlebih dahulu dilakukan penghitungan matriks korelasi yaitu korelasi antara peubah-peubah parameter kualitas kimia air dengan peubah-peubah parameter kualitas fisik air (Tabel 4).

Tabel 4: Matriks korelasi peubah-peubah parameter kualitas kimia air dan kualitas fisik air

\begin{tabular}{crrrrrrrrrr}
\hline Peubah & $Y_{1}$ & $Y_{2}$ & $Y_{3}$ & $Y_{4}$ & Peubah & $Y_{1}$ & $Y_{2}$ & $Y_{3}$ & $Y_{4}$ \\
\hline$X_{1}$ & 0.01 & 0.03 & 0.06 & -0.03 & $X_{13}$ & 0.05 & $-0.17^{*}$ & 0.03 & $0.15^{*}$ \\
$X_{2}$ & 0.04 & 0.01 & 0.01 & -0.01 & $X_{14}$ & -0.06 & -0.06 & -0.01 & -0.04 \\
$X_{3}$ & -0.05 & -0.06 & 0.12 & -0.08 & $X_{15}$ & 0.08 & -0.03 & 0.02 & 0.01 \\
$X_{4}$ & -0.07 & -0.03 & 0.05 & $0.13^{*}$ & $X_{16}$ & 0.05 & 0.05 & 0.09 & -0.01 \\
$X_{5}$ & 0.12 & -0.07 & -0.01 & 0.01 & $X_{17}$ & -0.01 & 0.06 & -0.09 & 0.03 \\
$X_{6}$ & 0.01 & 0.06 & -0.10 & 0.01 & $X_{18}$ & 0.02 & 0.01 & -0.01 & 0.02 \\
$X_{7}$ & -0.06 & 0.02 & 0.08 & 0.03 & $X_{19}$ & 0.03 & 0.06 & 0.05 & 0.03 \\
$X_{8}$ & 0.06 & 0.06 & 0.07 & 0.06 & $X_{20}$ & 0.01 & 0.02 & -0.04 & 0.08 \\
$X_{9}$ & 0.02 & 0.05 & -0.03 & 0.05 & $X_{21}$ & -0.06 & -0.08 & -0.01 & -0.04 \\
$X_{10}$ & 0.06 & 0.09 & $-0.13 *$ & -0.03 & $X_{22}$ & -0.07 & 0.03 & $-0.15^{*}$ & -0.02 \\
$X_{11}$ & 0.03 & -0.09 & -0.04 & -0.06 & $X_{23}$ & -0.01 & 0.02 & 0.11 & 0.02 \\
$X_{12}$ & 0.07 & 0.12 & -0.02 & -0.03 & $X_{24}$ & -0.07 & $-0.13 *$ & 0.01 & -0.06 \\
*signifikan pada taraf nyata $5 \%$ & & & & & & & &
\end{tabular}

Tabel 4 menunjukkan bahwa terdapat korelasi linier antara peubah parameter kualitas fisik air dengan peubah parameter kualitas kimia air, yaitu kadar zat tersuspensi dalam air dengan kadar fenol dalam air, kadar mangan dalam air dengan kadar zat terlarut dalam air, kadar nitrit dalam air dengan kadar zat tersuspensi dalam air, kadar nitrit dalam air dengan kadar zat tersuspensi dalam air, kadar sianida dalam air dengan kadar zat terlarut dalam air, dan kadar sulfida dalam air dengan temperatur air. Korelasi yang diukur pada korelasi linear tersebut hanya melihat hubungan antar peubah pada kedua parameter kualitas air. Oleh karena itu korelasi antara parameter kualitas fisik air dan parameter kualitas kimia air dilihat menggunakan analisis korelasi kanonik yang dapat mengukur keeratan hubungan antar parameter kualitas air serta mengurai pola hubungan antar peubah pada kedua parameter kualitas air tersebut dengan membentuk kombinasi linear dari setiap peubah pada parameter kualitas fisik air dan parameter kualitas kimia air sedemikian sehingga korelasi kedua parameter kualitas air tersebut menjadi maksimum. Pasangan dari kombinasi kanonik yang terbentuk disebut fungsi kanonik dan korelasi yang terbentuk disebut korelasi kanonik.

Banyaknya fungsi kanonik yang terbentuk sama dengan minimal banyaknya peubah dalam setiap parameter kualitas air. Dalam kasus ini, peubah-peubah parameter kualitas kimia air terdiri dari 24 peubah sedangkan peubah-peubah parameter kualitas fisik air hanya terdiri dari 4 peubah, maka akan terbentuk 4 fungsi kanonik.

Tabel 5 menunjukkan bahwa persentase keragaman yang diperoleh pada masingmasing fungsi kanonik bernilai kurang dari $50 \%$ yang berarti fungsi kanonik yang terbentuk kurang baik dalam menggambarkan keragaman asal. Oleh karena itu dilakukan langkah lebih lanjut dengan cara mengelompokkan peubah-peubah pada 
masing-masing parameter kualitas air. Pengelompokan dilakukan dengan tujuan diperolehnya keragaman yang lebih besar dengan adanya lebih banyak peubah yang digunakan.

Tabel 5: Nilai korelasi fungsi kanonik ke-i

\begin{tabular}{llll}
\hline $\begin{array}{l}\text { Fungsi kanonik } \\
\text { ke-i }\end{array}$ & Persentase & $\begin{array}{l}\text { Korelasi } \\
\text { kanonik }\end{array}$ & $\begin{array}{l}\text { Koefisien } \\
\text { determinasi }\end{array}$ \\
\hline 1 & 32.44 & 0.38 & 0.11 \\
2 & 30.92 & 0.33 & 0.11 \\
3 & 21.30 & 0.28 & 0.08 \\
4 & 15.34 & 0.24 & 0.06 \\
\hline
\end{tabular}

Tabel 6: Nilai rataan peubah-peubah parameter kualitas kimia air dan kualitas fisik

\begin{tabular}{|c|c|c|c|}
\hline No & Peubah baru & $\begin{array}{l}\text { Peubah } \\
\text { lama }\end{array}$ & $\begin{array}{c}\text { Nilai } \\
\text { rataan }\end{array}$ \\
\hline \multirow[t]{2}{*}{1} & \multirow{2}{*}{$\begin{array}{l}\text { Peubah parameter kualitas fisik } \\
\text { air yang tidak berbentuk }\left(F_{1}\right)\end{array}$} & $Y_{1}$ & 82.06 \\
\hline & & $Y_{3}$ & 52.33 \\
\hline \multirow[t]{2}{*}{2} & \multirow{2}{*}{$\begin{array}{l}\text { Peubah parameter kualitas fisik } \\
\text { air yang berbentuk }\left(F_{2}\right)\end{array}$} & $Y_{2}$ & 24.24 \\
\hline & & $Y_{4}$ & 40.21 \\
\hline \multirow{4}{*}{3} & \multirow{4}{*}{$\begin{array}{l}\text { Peubah parameter kualitas kimia air } \\
\text { yang bersifat logam }\left(\mathrm{K}_{1}\right)\end{array}$} & $X_{1}$ & 0.04 \\
\hline & & $X_{9}$ & 0.01 \\
\hline & & $X_{18}$ & 0.05 \\
\hline & & $X_{22}$ & 0.01 \\
\hline \multirow{10}{*}{4} & \multirow{10}{*}{$\begin{array}{l}\text { Peubah parameter kualitas kimia air } \\
\text { yang bersifat asam }\left(\mathrm{K}_{2}\right)\end{array}$} & $X_{2}$ & 0.46 \\
\hline & & $X_{5}$ & 0.33 \\
\hline & & $X_{8}$ & 47.71 \\
\hline & & $X_{10}$ & 0.30 \\
\hline & & $X_{12}$ & 5.90 \\
\hline & & $X_{13}$ & 0.34 \\
\hline & & $X_{15}$ & 7.20 \\
\hline & & $X_{17}$ & 51.55 \\
\hline & & $X_{21}$ & 0.01 \\
\hline & & $X_{23}$ & 0.47 \\
\hline \multirow{10}{*}{5} & \multirow{10}{*}{$\begin{array}{l}\text { Peubah parameter kualitas kimia air } \\
\text { yang bersifat basa }\left(K_{3}\right)\end{array}$} & $x_{3}$ & 118.66 \\
\hline & & $X_{4}$ & 6.14 \\
\hline & & $X_{6}$ & 0.01 \\
\hline & & $X_{7}$ & 15.30 \\
\hline & & $X_{11}$ & 1909.94 \\
\hline & & $X_{14}$ & 5.39 \\
\hline & & $X_{16}$ & 0.03 \\
\hline & & $X_{19}$ & 0.11 \\
\hline & & $X_{20}$ & 0.01 \\
\hline & & $X_{24}$ & 0.01 \\
\hline
\end{tabular}

Pengelompokan peubah pada masing-masing parameter kualitas air didasarkan pada kesamaan sifat yang dimiliki. Peubah parameter kualitas kimia air dibagi menjadi 
3 kelompok peubah baru, yaitu peubah parameter kualitas kimia air yang bersifat asam, peubah parameter kualitas kimia air yang bersifat basa, dan peubah parameter kualitas kimia air yang bersifat logam. Peubah parameter kualitas fisik air dibagi menjadi 2 kelompok peubah baru, yaitu peubah parameter fisika air yang berbentuk dan dan peubah parameter fisika air yang tidak berbentuk (KLH 2003). Pengelompokan dilakukan dengan metode penggerombolan tidak berhierarkhi. Peubah baru yang terbentuk dikelompokkan menggunakan fungsi jarak Euclidean yang diukur berdasarkan kemiripan rataan dari peubah-peubah parameter kualitas air, sehingga terdapat beberapa peubah yang berdasarkan sifat fisik dan kimianya dapat dikelompokkan ke dalam satu peubah yang sama. Namun, setelah dilakukan penggerombolan, beberapa peubah terpisah ke dalam kelompok peubah yang berbeda. Perbedaan tersebut disebabkan pengelompokkan dilakukan dengan menggunakan nilai rataan yang tidak memperhatikan fluktuasi nilai pada masingmasing peubah, sehingga meskipun terdapat beberapa peubah yang memiliki kesamaan antara sifat fisik dengan sifat kimianya,tetapi memiliki nilai rataan yang berbeda, maka peubah tersebut akan dikelompokkan ke dalam kelompok peubah yang berbeda.

Banyaknya fungsi kanonik yang terbentuk mengikuti minimal banyak peubah dalam setiap parameter kualitas air (Tabel 7). Dalam kasus ini, peubah-peubah parameter kualitas kimia air terdiri dari 3 peubah sedangkan peubah-peubah parameter kualitas fisik air hanya terdiri dari 2 peubah, maka akan terbentuk 2 fungsi kanonik pada setiap kombinasi pengelompokan peubah.

Tabel 7: Tabel kelompok peubah baru

\begin{tabular}{lll}
\hline No & Peubah Baru & $\begin{array}{l}\text { Peubah } \\
\text { Lama }\end{array}$ \\
\hline 1 & $\begin{array}{l}\text { Peubah fisika air yang tidak } \\
\text { berbentuk }\left(F_{1}\right)\end{array}$ & $Y_{1}$ dan $Y_{3}$ \\
2 & $\begin{array}{l}\text { Peubah fisika air yang berbentuk } \\
\text { ( }\end{array}$ & $Y_{2}$ dan $Y_{4}$ \\
& $\left(F_{2}\right)$ & \\
3 & Peubah kualitas kimia air yang & $X_{1}, X_{9}, X_{18}, X_{22}$ \\
& bersifat logam $\left(K_{1}\right)$ & $X_{2}, X_{5}, X_{8}, X_{10}$, \\
4 & Peubah kualitas kimia air yang & $X_{12}, X_{13}, X_{15}, X_{17}$, \\
& bersifat asam $\left(K_{2}\right)$ & $X_{21}, X_{23}$ \\
& & $X_{3}, X_{4}, X_{6}, X_{7}, X_{11}$, \\
5 & Peubah kualitas kimia air yang & $X_{14}, X_{16}, X_{19}, X_{20}$, \\
& bersifat basa $\left(K_{3}\right)$ & $X_{24}$ \\
\hline
\end{tabular}

Tabel 8 hingga Tabel 13 menunjukkan bahwa hanya menggunakan fungsi kanonik pertama keragaman yang mampu dijelaskan sudah di atas $50 \%$. Pasangan fungsi kanonik yang memiliki nilai korelasi paling tinggi adalah fungsi peubah parameter kualitas fisik air yang berbentuk yang terdiri dari temperatur air dan kadar zat tersuspensi dalam air dengan peubah parameter kualitas kimia air yang bersifat asam yang terdiri dari kadar besi dalam air, kadar fosfat dalam air, kadar COD dalam air, kadar mangan dalam air, kadar nitrat dalam air, kadar nitrit dalam air, kadar $\mathrm{pH}$ dalam air, kadar sulfat dalam air, kadar arsen dalam air, dan kadar klorin bebas dalam air. Meskipun nilai korelasi fungsi peubah parameter kualitas fisik air yang berbentuk dengan peubah parameter kualitas kimia air yang diperoleh memiliki korelasi yang 
lemah tetapi nilai korelasi tersebut merupakan nilai korelasi terbesar dibandingkan dengan nilai korelasi fungsi kanonik peubah parameter kualitas fisik air dan peubah parameter kualitas kimia air yang lain.

Tabel 8: Nilai korelasi kanonik peubah parameter fisik air yang tidak berbentuk dan peubah parameter kualitas kimia air yang bersifat logam

\begin{tabular}{llllll}
\hline $\begin{array}{l}\text { Fungsi Kanonik } \\
\text { ke-i }\end{array}$ & $\begin{array}{l}\text { Akar } \\
\text { Ciri }\end{array}$ & Persentase & $\begin{array}{l}\text { Persentase } \\
\text { Kumulatif }\end{array}$ & $\begin{array}{l}\text { Korelasi } \\
\text { Kanonik }\end{array}$ & $\begin{array}{l}\text { Koefisien } \\
\text { determinasi }\end{array}$ \\
\hline 1 & 0.03 & 96.54 & 96.54 & 0.18 & 0.03 \\
2 & 0.01 & 3.46 & 100.00 & 0.03 & 0.01 \\
\hline
\end{tabular}

Tabel 9: Nilai korelasi kanonik peubah parameter fisik air yang tidak berbentuk dan peubah parameter kualitas kimia air yang bersifat asam

\begin{tabular}{llllll}
\hline $\begin{array}{l}\text { Fungsi Kanonik } \\
\text { ke-i }\end{array}$ & $\begin{array}{l}\text { Akar } \\
\text { Ciri }\end{array}$ & Persentase & $\begin{array}{l}\text { Persentase } \\
\text { Kumulatif }\end{array}$ & $\begin{array}{l}\text { Korelasi } \\
\text { Kanonik }\end{array}$ & $\begin{array}{l}\text { Koefisien } \\
\text { determinasi }\end{array}$ \\
\hline 1 & 0.05 & 51.58 & 51.58 & 0.21 & 0.04 \\
2 & 0.04 & 48.42 & 100.00 & 0.20 & 0.04 \\
\hline
\end{tabular}

Tabel 10: Nilai korelasi kanonik peubah parameter fisik air yang tidak berbentuk dan peubah parameter kualitas kimia air yang bersifat basa

\begin{tabular}{llllll}
\hline $\begin{array}{l}\text { Fungsi Kanonik } \\
\text { ke-i }\end{array}$ & $\begin{array}{l}\text { Akar } \\
\text { Ciri }\end{array}$ & Persentase & $\begin{array}{l}\text { Persentase } \\
\text { Kumulatif }\end{array}$ & $\begin{array}{l}\text { Korelasi } \\
\text { Kanonik }\end{array}$ & $\begin{array}{l}\text { Koefisien } \\
\text { determinasi }\end{array}$ \\
\hline 1 & 0.05 & 70.82 & 70.82 & 0.22 & 0.05 \\
2 & 0.02 & 29.18 & 100.00 & 0.14 & 0.02 \\
\hline
\end{tabular}

Tabel 11: Nilai korelasi kanonik peubah parameter fisik air yang berbentuk dan peubah parameter kualitas kimia air yang bersifat logam

\begin{tabular}{llllll}
\hline $\begin{array}{l}\text { Fungsi Kanonik } \\
\text { ke-i }\end{array}$ & $\begin{array}{l}\text { Akar } \\
\text { Ciri }\end{array}$ & Persentase & $\begin{array}{l}\text { Persentase } \\
\text { Kumulatif }\end{array}$ & $\begin{array}{l}\text { Korelasi } \\
\text { Kanonik }\end{array}$ & $\begin{array}{l}\text { Koefisien } \\
\text { determinasi }\end{array}$ \\
\hline 1 & 0.01 & 62.99 & 62.99 & 0.07 & 0.01 \\
2 & 0.01 & 37.00 & 100.00 & 0.05 & 0.01 \\
\hline
\end{tabular}

Tabel 12: Nilai korelasi kanonik peubah parameter fisik air yang berbentuk dan peubah parameter kualitas kimia air yang bersifat asam

\begin{tabular}{llllll}
\hline $\begin{array}{l}\text { Fungsi Kanonik } \\
\text { ke-i }\end{array}$ & $\begin{array}{l}\text { Akar } \\
\text { Ciri }\end{array}$ & Persentase & $\begin{array}{l}\text { Persentase } \\
\text { Kumulatif }\end{array}$ & $\begin{array}{l}\text { Korelasi } \\
\text { Kanonik }\end{array}$ & $\begin{array}{l}\text { Koefisien } \\
\text { determinasi }\end{array}$ \\
\hline 1 & 0.09 & 83.42 & 83.42 & 0.29 & 0.08 \\
2 & 0.02 & 16.58 & 100.00 & 0.13 & 0.02 \\
\hline
\end{tabular}

Tabel 13: Nilai korelasi kanonik peubah parameter fisik air yang berbentuk dan peubah parameter kualitas kimia air yang bersifat logam

\begin{tabular}{llllll}
\hline $\begin{array}{l}\text { Fungsi Kanonik } \\
\text { ke-i }\end{array}$ & $\begin{array}{l}\text { Akar } \\
\text { Ciri }\end{array}$ & Persentase & $\begin{array}{l}\text { Persentase } \\
\text { Kumulatif }\end{array}$ & $\begin{array}{l}\text { Korelasi } \\
\text { Kanonik }\end{array}$ & $\begin{array}{l}\text { Koefisien } \\
\text { determinasi }\end{array}$ \\
\hline 1 & 0.07 & 75.87 & 75.87 & 0.26 & 0.07 \\
2 & 0.02 & 24.13 & 100.00 & 0.15 & 0.02 \\
\hline
\end{tabular}

Fungsi kanonik yang diperoleh merupakan kombinasi linear antara dua 
kelompok peubah baru dengan menghitung nilai akar ciri dan vektor ciri padanannya dari masing-masing korelasi yang dilakukan, yaitu fungsi kanonik peubah parameter fisik air yang berbentuk $\left(F_{2}\right)$ dan peubah parameter kualitas kimia air yang bersifat asam $\left(K_{2}\right): F 2=0.88 Y_{2}-0.5 Y_{4}$

$$
\begin{gathered}
K 2=0.08 X_{2}-0.27 X_{5}+0.04 X_{8}+0.28 X_{10}-0.42 X_{12}-0.8 X_{13}+0.06 X_{15}-0.13 X_{17} \\
-0.08 X_{21}+0.4 F_{23}
\end{gathered}
$$

Pasangan fungsi kanonik yang terbentuk dapat menunjukkan korelasi peubah parameter kualitas fisik air dengan peubah parameter kualitas kimia air yang diperoleh dengan mengalikan korelasi kanonik pada pasangan fungsi kanonik dengan nilai koefisien masing-masing peubah ditunjukkan pada Tabel 14.

Tabel 24: Korelasi peubah parameter kualitas fisik terhadap gugus kimia air

\begin{tabular}{ccc}
\hline Peubah & $Y_{2}$ & $Y_{4}$ \\
\hline$K_{2}$ & 0.26 & -0.14 \\
\hline
\end{tabular}

Tabel 14 menunjukkan bahwa parameter kualitas kimia air yang bersifat asam yaitu peubah kadar besi dalam air, kadar fosfat dalam air, kadar COD dalam air, kadar mangan dalam air, kadar nitrat dalam air, kadar nitrit dalam air, kadar pH dalam air, kadar sulfat dalam air, kadar arsen dalam air, dan kadar klorin bebas dalam air dapat diindikasi oleh kadar temperatur air dengan nilai korelasi 0.255543 dan kadar zat tersuspensi dalam air dengan nilai korelasi -0.1452 .

Interpretasi fungsi kanonik dilakukan dengan mencari nilai bobot kanonik (canonical weights) dan muatan kanonik (canonical loadings).

1. Bobot Kanonik

Bobot kanonik dilihat berdasarkan besarnya kontribusi peubah asal terhadap peubah kanonik.

Tabel 15: Bobot kanonik bagi peubah parameter kualitas fisik air yang berbentuk

\begin{tabular}{ccc}
\hline Peubah & 1 & 2 \\
\hline$Y_{2}$ & 0.88 & 0.48 \\
$Y_{4}$ & -0.50 & 0.87 \\
\hline
\end{tabular}

Tabel 36: Bobot kanonik bagi peubah kualitas kimia air yang bersifat asam

\begin{tabular}{crc}
\hline Peubah & \multicolumn{1}{c}{1} & \multicolumn{1}{c}{2} \\
\hline$X_{2}$ & 0.08 & 0.049 \\
$X_{5}$ & -0.27 & -0.18 \\
$X_{8}$ & 0.04 & 0.52 \\
$X_{10}$ & 0.28 & 0.16 \\
$X_{12}$ & 0.42 & 0.15 \\
$X_{13}$ & -0.80 & 0.43 \\
$X_{15}$ & -0.06 & -0.08 \\
$X_{17}$ & 0.13 & 0.31 \\
$X_{21}$ & -0.08 & -0.55 \\
$X_{23}$ & -0.04 & 0.18 \\
\hline
\end{tabular}

Bobot kanonik masing-masing peubah pada Tabel 15 dan Tabel 16 
menunjukkan bahwa temperatur air, kadar zat tersuspensi dalam air dan kadar nitrit dalam air memiliki hubungan erat dengan peubah kanonik pertama.

2. Muatan Kanonik

Muatan kanonik dilihat berdasarkan besarnya korelasi antara peubah asal dengan masingmasing peubah kanoniknya. Semakin besar nilai loading mencerminkan semakin dekat hubungan fungsi kanonik yang bersangkutan dengan peubah asal.

Tabel 17: Bobot kanonik bagi peubah parameter kualitas fisik air

\begin{tabular}{crc}
\multicolumn{3}{c}{ yang berbentuk } \\
\hline Peubah & 1 & 2 \\
\hline$Y_{2}$ & 0.87 & 0.50 \\
$Y_{4}$ & -0.47 & 0.88 \\
\hline
\end{tabular}

Tabel 48: Bobot kanonik bagi peubah kualitas kimia air yang bersifat asam

\begin{tabular}{crr}
\hline Peubah & \multicolumn{1}{c}{1} & \multicolumn{1}{c}{2} \\
\hline$X_{2}$ & 0.04 & 0.03 \\
$X_{5}$ & -0.24 & -0.16 \\
$X_{8}$ & 0.07 & 0.57 \\
$X_{10}$ & 0.33 & 0.16 \\
$X_{12}$ & 0.42 & 0.22 \\
$X_{13}$ & -0.78 & 0.37 \\
$X_{15}$ & -0.11 & -0.09 \\
$X_{17}$ & 0.12 & 0.42 \\
$X_{21}$ & -0.167 & -0.52 \\
$X_{23}$ & -0.04 & 0.18 \\
\hline
\end{tabular}

Muatan kanonik masing-masing peubah pada Tabel XVII dan Tabel XVIII menunjukkan bahwa temperatur air dan kadar nitrit dalam air memiliki hubungan erat dengan peubah kanonik pertama.

\section{Simpulan}

Adanya hubungan yang signifikan antara parameter kualitas fisik air dan parameter kualitas kimia air sungai. Analisis korelasi kanonik yang dilakukan menghasilkan satu fungsi kanonik terbaik, yaitu: $F 2=0.88 Y_{2}-0.5 Y_{4}$

$$
\begin{gathered}
K 2=0.08 X_{2}-0.27 X_{5}+0.04 X_{8}+0.28 X_{10}-0.42 X_{12}-0.8 X_{13}+0.06 X_{15}-0.13 X_{17} \\
-0.08 X_{21}+0.4 F_{23}
\end{gathered}
$$

Fungsi kanonik yang terbentuk menunjukkan adanya korelasi antara peubahpeubah parameter kualitas fisik air yaitu temperatur air dan kadar zat tersuspensi dalam air dengan peubah-peubah parameter kualitas kimia air yakni kelompok logam (kadar mangan dalam air dan kadar besi dalam air) dan kelompok asam air (kadar fosfat dalam air, kadar sulfat dalam air, kadar nitrit dalam air, dan kadar nitrat dalam air). Hubungan antar parameter kualitas fisik air tersebut yaitu bernilai positif antara temperatur air dengan parameter kualitas kimia air dan bernilai negatif antara kadar zat tersuspensi dalam air dengan parameter kualitas kimia air. 


\section{Daftar Pustaka}

Djarismawati (1991). Tinjauan Penelitian Kadar Logam Berat pada Sungai di DKI Jakarta. Depok (ID): Dini S.

Matjik AA, S. I. (2011). Sidik Peubah Ganda dengan Menggunakan SAS. Bogor (ID): IPB Press.

RA Johnsen, W. (2007). Applied Multivariate Statistical Analysis Sixth Edition. New Jersey (US): Pearson Prentice Hall. 